\title{
Hydro-fracturing test in sandstone rock mass: A case study from Himalayas
}

\author{
GV Ramana, Shashank Pathak, KK Mishra and Hari Dev \\ Central Soil and Materials Research Station \\ Ministry of Water Resources \\ New Delhi, India \\ gv.ramana@nic.in
}

\begin{abstract}
Rock mass are naturally occurring construction materials which are subjected to in-situ stresses. In-situ stresses occur due to the weight of overburden and tectonic stresses. Prior knowledge of in-situ stresses is important before aligning the longitudinal structures in rock mass such as tunnels and powerhouse. During excavation in rock mass, insitu stresses get redistributed around the openings and sometimes may cause instability of the opening. Therefore, proper design of support system and alignment of the cavity requires determination of in -situ stresses.
\end{abstract}

In the present paper, a case study of hydro-fracturing test conducted by the authors at powerhouse site of Thana-Plaun hydroelectric project situated in Himachal Pradesh is discussed. The power house cavern will house 3 nos. of main generating units of 50.33 MW each and 2 nos. of environmental units of 20 MW each (Total capacity 191 MW). The rock type encountered in the area is represented by fresh, hard and compact sandstone with subordinate siltstone and claystone bands having gradations contacts and dipping towards upstream. The average bedding dip value is of the order of $57^{0}$ in $\mathrm{N}^{075^{\circ}}$ direction. In addition, five joint sets have been deciphered in the area.

A total of 14 tests, 5 in vertical drill holes and 9 in two horizontal drill holes have been conducted. These tests were conducted in three orthogonal boreholes of $30 \mathrm{~m}$ depth in the exploratory drift at powerhouse site. The results of these tests have been used to determine the in-situ horizontal and vertical stresses along with their orientation for the purpose of alignment of powerhouse. Average Orientation of maximum horizontal Stress was found to be $N{78^{\circ}}^{\circ}$ E. Maximum horizontal stress and minimum horizontal stress were found to be 5.49 $\mathrm{MPa}$ and 3.07 $\mathrm{MPa}$, respectively. Measured vertical stress was found to be $3.45 \mathrm{MPa}$, whereas, estimated vertical stress based on overburden depth is 3.32 MPa. Further, it is found that lateral earth pressure coefficient at state of rest $\left(K_{0}\right)$ i.e. ratio of horizontal stress to vertical stress for rock mass varies from 0.89 to 1.59 in the two horizontal directions.

Keywords-In-situ stress, hydro fracturing, sand stone, alignment of powerhouse, Rock mass

\section{INTRODUCTION}

All fractures and deformations in rock are the result of forces loading the rocks beyond their elastic limit. As regional deformation patterns appear to have been in existence for long period of time, the more recent geologic deformations may provide an indication of the most likely ground stress directions existing at present. Stresses found in rock can be grouped according to their origin as; Natural stresses and Induced stresses. A detailed discussion on this can be found in $[1,2,7,13]$. Natural stresses are the stresses found in rock before excavation and induced stresses are the result of stress changes due to man made excavation. Natural stresses include gravitational, tectonic, residual and thermal stresses. These stresses are most important for the underground structures and engineering. Stresses caused by underground excavation depend upon the shape of the excavation. However, from engineering point of view, the gravitational stresses and induced stresses are most important as they mainly influence the design and construction of the underground structures.

The orientation of long dimension of the cavern should be avoided perpendicular to the maximum principal stress. The shape of the cavern should be selected to minimize the stress concentration. Pressure tunnel, penstock and similar structures can be constructed and operated without lining, if the in-situ stresses are greater than the internal water pressure. Stresses can be estimated from estimation of vertical stress and a known value of the stress ratio. In recent years, it has been established that in-situ stress plays an important role in the location, design and construction of underground structures. Hast (1958) found that horizontal stresses often exceeds by 1.3 to 1.5 times the vertical stress and in extreme cases it goes upto 8 times. Works by Dewey (1972), Mckenzie and Sclater (1973), Courtillot and Vink (1983) further corroborated and verified the plate tectonics hypothesis by contributing substantial evidence about the driving forces between continents. Actual measurements of stresses suggested that ratio is very high at shallow depth and it decreases at depth [1,9].

There are several methods of stress measurement. For example, Hydraulic Fracturing, Sleeve Fracturing, Hydraulic Tests on Pre-existing Fractures (HTPF), Surface Relief Methods, Under Coring, Borehole Relief Methods (Overcoring, Borehole Slotting), Relief of Large Rock Volumes (Bored Raise, Under Excavation Techniques, Flat Jack Method, Curved Jack Method, Anelastic Strain Recovery (ASR), Differential strain curve analysis (DSCA), Caliper and dipmeter analysis, Borehole Televiewer 
Analysis (C. Ljunggrenaet et al, 2003). All the tests have their own advantages and disadvantages.

Out of these, the hydraulic fracturing technique is used in the present paper, a case study of hydro-fracturing test conducted by the authors at powerhouse site of Thana-Plaun hydroelectric project situated in Himachal Pradesh is discussed. A total of 14 tests, 5 in vertical drill holes and 9 in two horizontal drill holes have been conducted. These tests are conducted in three orthogonal boreholes of $30 \mathrm{~m}$ depth in the exploratory drift at powerhouse site. The results of these tests are used to determine the in-situ stresses along with their orientation for the purpose of alignment of powerhouse. Thana Plaun Hydro-electric project involves the construction of $106.70 \mathrm{~m}$ high (from deepest foundation level) and $221.25 \mathrm{~m}$ long concrete gravity dam.

In-situ stresses are already present due to various geological and tectonic reasons. The excavation of tunnel changes the primary stress field into a three dimensional pattern at the tunnelling face. Knowledge of these stresses is of utmost importance in the dimensioning and alignment of tunnel and proportioning of tunnel lining. In most of the cases, in-situ measured values of $\sigma_{-} \mathrm{h} / \sigma_{-} \mathrm{v}$ lie between 0.5 and 0.8 for hard rock, and between $0 . \overline{8}$ and 1.0 for soft or inelastic rocks such as shale or salt. In number of instances $\sigma_{-} \mathrm{h} / \sigma_{-} \mathrm{V}$ has been found to be greater than 2.0 also. In present case, this ratio has been found to be 0.89 to 1.59 .

Thus, for the design purpose, the vertical stress can be estimated from the gravity load. However, a realistic horizontal stress can be found only after in-situ stress determination. For design of tunnel lining, a rock-structure interaction curve (Characteristics for the interaction of ground and support for circular tunnel cross section (FennerPacher curve); Engineering in rock masses / edited by F.G. Bell; with specialist contributions. Butterworth-Heinemann, 1992) are required for evaluation of the support best suited to the conditions. In-situ stress is one of the important input parameter for this analysis.

\section{POWER HOUSE DRIFT}

The area around the power house complex is represented by fresh, hard and compact sandstone with subordinate siltstone and claystone bands having gradations contacts and dipping towards upstream. The joint set details of power house of drift is given in the Table I.

There is adequate top and side cover above the caverns. Sandstone will offer a good tunneling media and most of it will fall in the category II and III. However, where thicker clayey bands shears and wet zones are intercepted, the class of rock would fall to class IV and V and anticipated to have adequate stand-up time. Since, the excavation has to be done in segments with concurrent supporting so no major problems are anticipated. Unfavourable rock wedges shall call for concurrent supporting. Most of the excavation in class II and III could be managed by rock bolts and shotcreting. The lower class rock would call for stronger and concurrent supports. Drainage arrangement may have to be provided in higher charge zones.
TABLE I: JOINT SET DATA IN POWER HOUSE DRIFT

\begin{tabular}{|c|c|c|c|c|}
\hline \multirow[t]{2}{*}{ S. No. } & \multirow[t]{2}{*}{ Set No. } & \multicolumn{2}{|c|}{ Dip } & \multirow[t]{2}{*}{ Strike } \\
\hline & & Amount & Direction & \\
\hline 1. & $\mathrm{~J} 1$ (BP) & 57 & N075 & $\mathrm{N} 165^{0}-\mathrm{N} 345^{\circ}$ \\
\hline 2. & $\mathrm{~J} 2$ & 23 & $\mathrm{~N} 267^{0}$ & $\mathrm{~N} 177^{0}-\mathrm{N} 357^{0}$ \\
\hline 3. & $\mathrm{~J} 3$ & 67 & $\mathrm{~N} 152^{0}$ & $\mathrm{~N} 062^{0}-\mathrm{N} 242^{0}$ \\
\hline 4. & $\mathrm{~J} 4$ & 74 & $\mathrm{~N} 189^{\circ}$ & $\mathrm{N} 009^{0}-\mathrm{N} 229^{0}$ \\
\hline 5. & $\mathrm{~J} 5$ & 72 & $\mathrm{~N} 339^{0}$ & $\mathrm{~N} 069^{0}$ - N249 \\
\hline 6. & J6 & 53 & $\mathrm{~N} 030^{\circ}$ & $\mathrm{N} 120^{\circ}-\mathrm{N} 300^{\circ}$ \\
\hline
\end{tabular}

Note: BP - Bedding Plane

\section{TEST LOCATIONS}

The hydro-fracturing tests were conducted in two horizontal drillholes DHF-1 (H) and DHF-3 (H) at RD $25 \mathrm{~m}$ of left cross cut from junction and in one vertical drillhole DHF-2 (V) at same RD $25 \mathrm{~m}$ the power house drift. Total 5 tests were conducted in vertical drill hole No. DHF-1(V) between $4.60 \mathrm{~m}$ to $10.89 \mathrm{~m}$. Total 9 tests were conducted in 2 horizontal drill holes No. DHF-1(H) (between $4.60 \mathrm{~m}$ to $26.68 \mathrm{~m}$ ) and DHF-3(H) (between $7.55 \mathrm{~m}$ to $14.15 \mathrm{~m}$ ).

\section{A. Geology of Drillholes}

The drillholes were of 'EX' size $(38 \mathrm{~mm})$ and drilled upto $30 \mathrm{~m}$. Parent rock encountered was grey sandstone with thin bands of siltstone/ shale. Geological logs of the drillhole shows that the rock encountered is jointed and usually broken into pieces at the bands. In the horizontal drillhole DHF-1 $(\mathrm{H})$ the rock encountered was grey sandstone with thin bands of siltstone/ shale. RQD varied from $23-90 \%$ and core recovery varied from $22-82 \%$. In another horizontal drillhole DHF-3 $(\mathrm{H})$ also the rock encountered was grey sandstone with thin bands of siltstone/ shale. RQD varied from $18-100 \%$ and core recovery varied from $24-78 \%$. In the vertical drillhole DHF-2 (V) the rock encountered was grey sandstone with thin bands of siltstone/ shale. RQD varied from $58-84 \%$ and core recovery varied from $6-66 \%$. Bearing of the horizontal drillholes DHF-1 (H) \& DHF-3 (H) are $265^{\circ}$ and $355^{\circ}$, respectively.

\section{B. Brief procedure, terminology and equipment details (ISRM (1981))}

In recent years, the hydraulic fracturing technique has become popular with mining and civil engineering projects and also for structural geology, plate tectonics and earthquake mechanics

The method essentially consists of:

- Drilling of EX size drillholes

- Selecting test locations after inspecting the cores of drillhole rock, 
- Isolating the test section with the help of packers,

- Pressurising the test location to obtain a fracture in the rock,

- Obtaining a pressure time record, and

- Obtaining the impression of the crack on an impression packer.

Water, with soluble oil, has been used and found to be the most appropriate and convenient test fluid. The field test procedure involves an initial fracturing followed by a number of cycles of re-pressurisation. Initial fracturing is accomplished by increasing the pressure in the test section along with simultaneous increase in the packer pressure which is always slightly higher than the pressure in test section. Pumping is stopped as soon as a crack is formed (indicated by sudden drop in test section pressure) in order to preserve the initial geometry of the induced crack (as recorded by the impression packer) and to allow a first shut in pressure to be recorded.

A relatively slow pressurisation rate is employed to ensure that the initiated crack retains its initial geometry during the first shut in phase. The test interval is vented to allow the induced crack to close. A buildup of pressure in the test interval upon temporarily sealing the system during venting is taken as evidence of continued flow of fluid out of a closing crack. Venting is continued until this phenomenon ceases.

Further cycles of pressurisation and venting are used to determine the crack re-opening pressure and to gauge whether the orientation of the crack changes as it is propagated. Pressure versus time plot is recorded during the test. The impression of the crack is taken on the impression packer by lowering it in the drillhole at the test location and pressurising it taking account of the orientation of the lowering rods as well as the fracture initiation/reopening pressure. The direction of the crack is marked on the impression packer and is recorded on the record sheet. This direction of crack gives the direction of maximum stresses in a plane perpendicular to the vertical drillhole axis.

\section{Interpretation of Stresses}

The fundamental principle underlying the application of hydraulic fracturing is that

- One of the principal stress components is co-axial with the test hole,

- The long-term shut in pressure is approximated as the magnitude of the secondary/ minor horizontal stress component.

- The crack will generally tend to initiate in a plane normal to minimum stress (i.e. along the maximum stress)

In the case of an approximately axial fracture in a hole, the test pressure record can be used to estimate the magnitude of secondary principal stresses in the plane normal to the drillhole axis.

The magnitude of maximum secondary principal stress component for impermeable rocks is determined from the expression:
Where,

$$
\sigma_{1}{ }^{\prime}=3 \sigma_{2}{ }^{\prime}+\mathrm{S}-\mathrm{P}_{\mathrm{i}}-\mathrm{P}_{\mathrm{o}}
$$

$\sigma_{1}{ }^{\prime}$ is maximum secondary stress,

$\sigma_{2}^{\prime}$ is minimum secondary stress, $\mathrm{S}$ is fracture strength of the rock,

$\mathrm{P}_{\mathrm{i}}$ is fracture initiation pressure, and $\mathrm{P}_{\mathrm{o}}$ is ambient pore pressure.

The magnitude of minimum secondary principal stress is equal to the shut-in pressure $\left(\mathrm{S}_{\mathrm{i}}\right)$.

Therefore,

$$
\sigma_{2}^{\prime}=\mathrm{S}_{\mathrm{i}}
$$

The fracture strength, ' $S$ ' can be found from the expression:

where,

$$
\mathrm{S}=\mathrm{P}_{\mathrm{i}}-\mathrm{P}_{\mathrm{r}}
$$

$\mathrm{P}_{\mathrm{r}} \quad$ = fracture reopening pressure.

Equation 3 can be rewritten as

$$
\mathrm{S}-\mathrm{P}_{\mathrm{i}}=\mathrm{P}_{\mathrm{r}}
$$

Neglecting $\mathrm{P}_{\mathrm{o}}$ term, as the ambient pore pressure can normally be assumed to have been dissipated in the close proximity of an underground opening; the Eq.1 can be rewritten as follows with the help of Eq.4:

$$
\sigma_{1}{ }^{\prime}=3 \sigma_{2}{ }^{\prime}-P_{\mathrm{r}}
$$

$\mathrm{P}_{\mathrm{i}}, \mathrm{P}_{\mathrm{r}}$ and $\mathrm{S}_{\mathrm{i}}$ can be obtained from pressure time record. $\mathrm{S}_{\mathrm{i}}$ is calculated by the double tangent method.

The vertical stress is estimated from the depth of overburden rock by:

$$
\sigma_{\mathrm{v}}=\gamma \mathrm{h}
$$

Where,

$$
\begin{aligned}
& \sigma_{\mathrm{v}}=\text { vertical stress, } \\
& \mathrm{h}=\text { depth of overburden, and } \\
& \gamma=\text { average density of rock mass }
\end{aligned}
$$

Direction of the stresses is determined from the impressions of the induced cracks obtained on the impression packer. These directions are obtained with reference to true North.

The parent rock strata encountered at the vertical location was grey sandstone with thin bands of siltstone/ shale. RQD in vertical drillholes DHF-2 (V) varied from 58$84 \%$. The good RQD may be because of the less joint pattern and banding nature of sand stone. By inspecting the cores of drillholes, the test locations were decided. Therefore, 14 hydro-fracturing tests could be conducted in three drillholes (1-vertical and 2-horizontal) at RD $25 \mathrm{~m}$ towards left cross cut from junction in the power house drift of Thana Plaun H.E. Project, Mandi, Himachal Pradesh. Details of the tests are given in Table II. 


\section{RESUlTS AND DisCUSSIONS}

\section{A. Stresses in Vertical Drillhole}

A total Five tests in drillhole DHF-2 (V) were conducted at possible depths (based on the drillhole cores) to measure the stresses in vertical drillhole at RD $25 \mathrm{~m}$ towards left cross cut from junction in the power house drift. The test results have been presented in Table II. Magnitudes of minimum and maximum horizontal stresses were calculated from the pressure Vs time plots of the tests conducted in the vertical drillholes. The direction of maximum horizontal stress was determined from three impression records of the fracture. For example, Pressure versus time plot and fracture impression record of Test Nos. 1 of drillhole DHF-2 (V) has been shown in Fig.s 1 and 2, respectively.

\section{StResses in Horizontal Drillholes}

Five tests in drillhole DHF-1 $(\mathrm{H})$ and four tests in drillhole DHF-3 $(\mathrm{H})$ were conducted at different depths (based on the drillhole cores) to determine the stresses in horzontal drillholes at RD $25 \mathrm{~m}$ towards left cross cut from junction in the power house drift. The test results have been presented in Table III. Magnitudes of stresses were calculated from the pressure Vs time plots of the tests conducted in the horizontal drillholes.

The direction of maximum stress was determined from five impression records of the fracture. For example, pressure versus time plot and fracture impression record of Test Nos. 6 of drillhole DHF-1 (H) have been shown in Fig.s 3 and 4, respectively. On the basis of tests conducted in the horizontal drill hole, minimum and maximum stresses were calculated.

The maximum and minimum stresses in the horizontal drill holes vary from 4.14 MPa to $6.21 \mathrm{MPa}$ and 2.76 $\mathrm{MPa}$ to $3.45 \mathrm{MPa}$, respectively. The average measured maximum and minimum stresses are found to be $4.81 \mathrm{MPa}$ and 2.94 $\mathrm{MPa}$, respectively. Since, the orientation of fracture with respect to the top of the drillhole was at $80^{\circ}$ in DHF-03 drillhole (Test No. T14), the minimum stress i.e. $3.45 \mathrm{MPa}$ determined from this test was considered as measured vertical stress.

TABLE II: IN-SITU STRESSES FROM VERTICAL DRILLHOLES DHF-2 (V) (CSMRS, 2014)

\begin{tabular}{|c|c|c|c|c|c|c|c|c|c|}
\hline \multirow{2}{*}{ 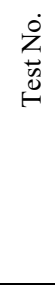 } & \multicolumn{2}{|c|}{$\begin{array}{l}\text { Test Depth } \\
\text { (m) }\end{array}$} & \multirow[b]{2}{*}{ 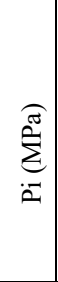 } & \multirow[b]{2}{*}{$\sum_{=}^{\pi}$} & \multirow[b]{2}{*}{ 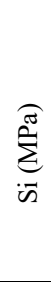 } & \multirow{2}{*}{ 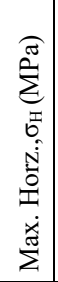 } & \multirow{2}{*}{ 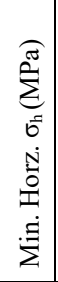 } & \multirow[b]{2}{*}{$\sum_{0}^{\sum_{0}^{E}}$} & \multirow{2}{*}{ 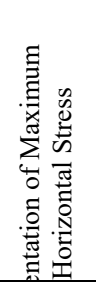 } \\
\hline & 옹 & $\stackrel{0}{H}$ & & & & & & & \\
\hline \multicolumn{10}{|c|}{ Location =1, RD 175 m, DHF-2, Vertically downward } \\
\hline $\mathrm{T} 1$ & $\begin{array}{l}\infty \\
0 \\
0\end{array}$ & กิ & 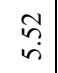 & $\stackrel{\infty}{i}$ & ñ & $\begin{array}{l}8 \\
\text { i }\end{array}$ & ๙ุ & $\begin{array}{l}\infty \\
n \\
n\end{array}$ & ' \\
\hline $\mathrm{T} 2$ & $\stackrel{n}{0} 0$ & $\frac{尺}{a}$ & तै & $\stackrel{\infty}{\infty}$ & $=$ & $\begin{array}{l}n \\
n \\
n\end{array}$ & $\begin{array}{l}\exists \\
\dot{m}\end{array}$ & $\begin{array}{l}n \\
n \\
n\end{array}$ & §ै山 \\
\hline T3 & in & $\frac{9}{1}$ & 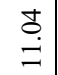 & $\dddot{q}$ & $\begin{array}{l}\infty \\
\infty \\
\dot{m}\end{array}$ & ڤి & $\begin{array}{l}\infty \\
\dot{m}\end{array}$ & $\vec{n}$ & $\stackrel{\stackrel{N}{Z}}{Z}$ \\
\hline T4 & $\stackrel{0}{0}$ & $\dot{r}$ & $\therefore \mathscr{}$ & $\ddot{+}$ & $\dot{r} \sim$ & 그- & $\stackrel{t i n}{m}$ & $\stackrel{\nabla}{\dot{m}} n$ & $\stackrel{Z}{Z}^{\infty} \circ$ 피 \\
\hline T5 & in & $\stackrel{\bullet}{+}$ & $\begin{array}{l}\tilde{b} \\
\infty \\
\infty\end{array}$ & $m$ & $\stackrel{\stackrel{\sim}{\sim}}{\sim}$ & $\begin{array}{l}\infty \\
\dot{\infty}\end{array}$ & $\stackrel{\stackrel{\sim}{\sim}}{\sim}$ & $\begin{array}{l}\underset{v}{*} \\
\dot{r}\end{array}$ & ' \\
\hline
\end{tabular}

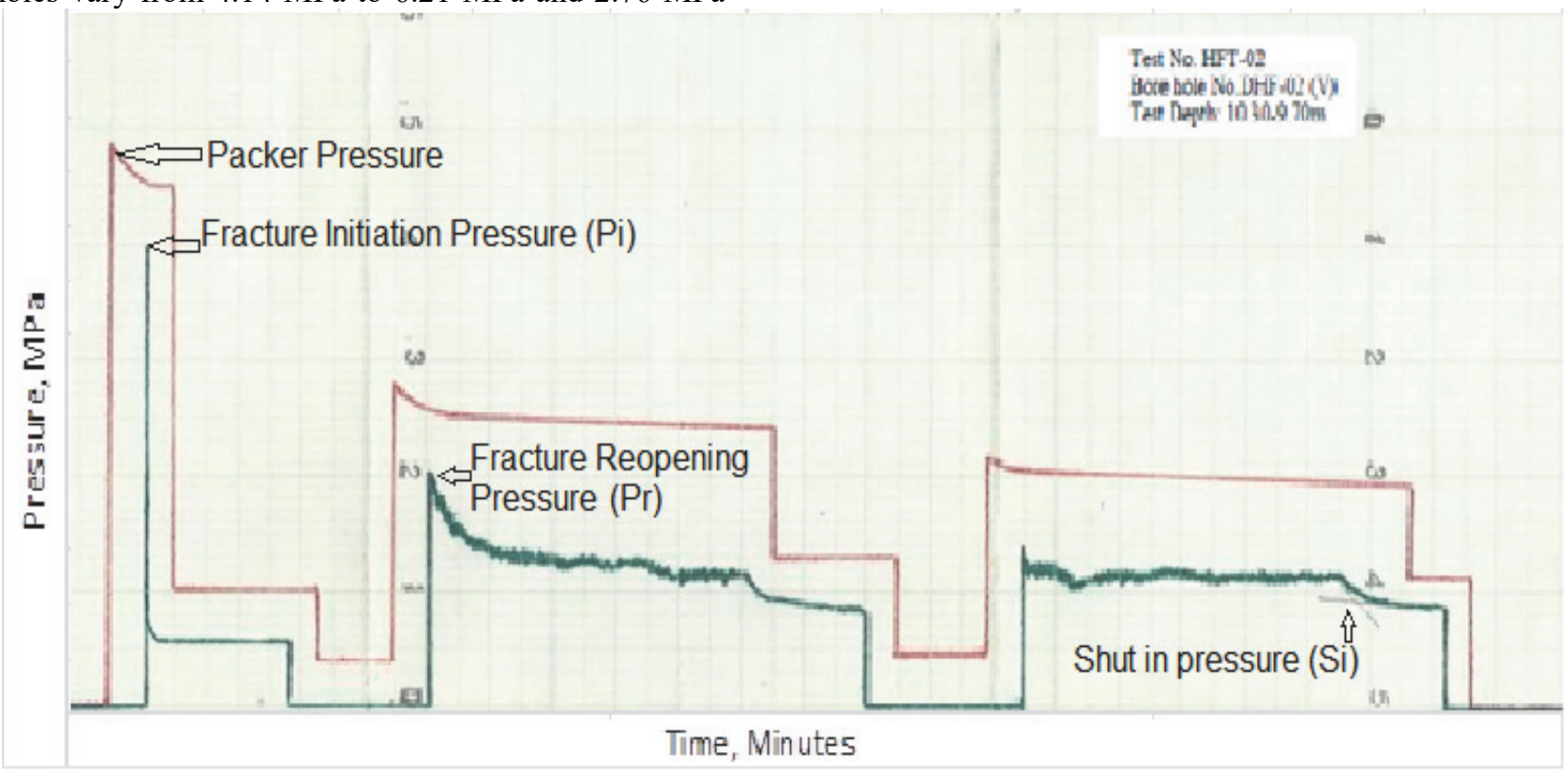

Fig. 1: Pressure V/s Time plot for Test No. 2 in DHF-2 (V) (CSMRS, 2014) 


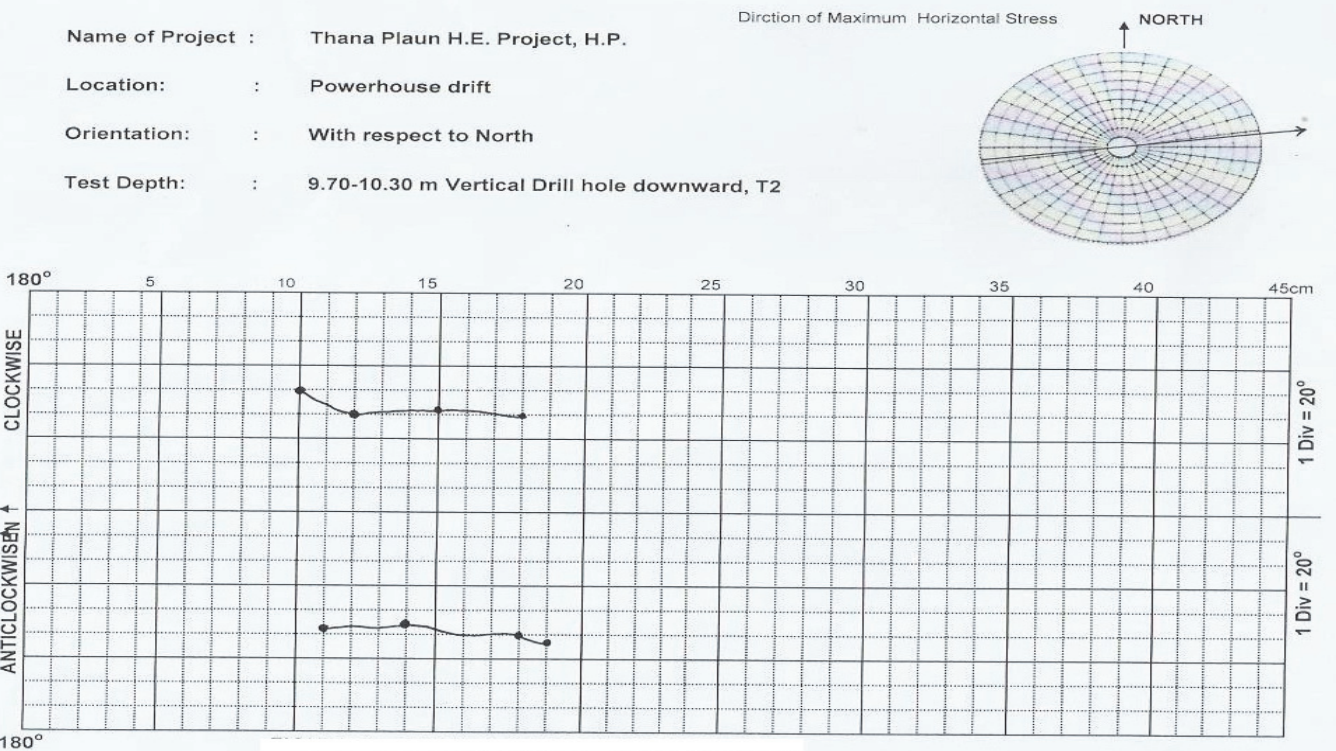

Fig. 2: Fracture impression record of Test No. 2 in DHF-2 (V) (CSMRS, 2014)

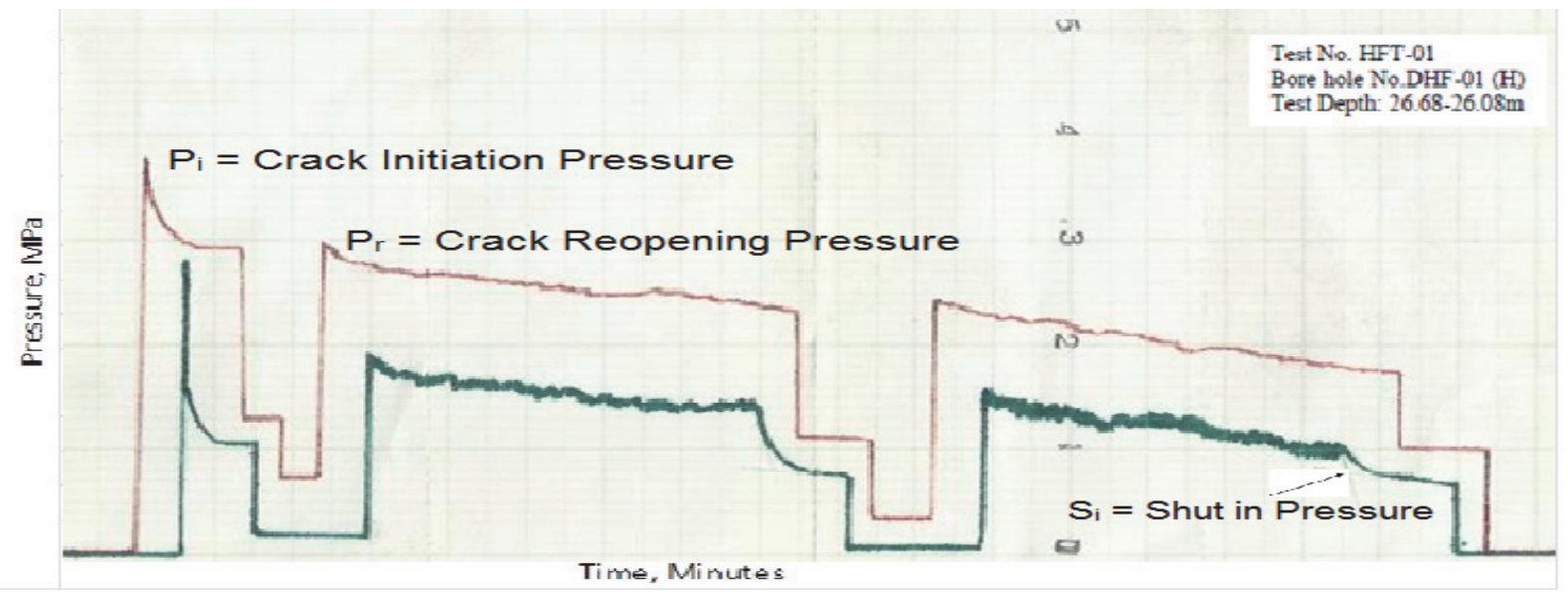

Fig. 3: Pressure V/s Time plot Record of Hydrofracturing Test No. 6 (DHF-1) (CSMRS, 2014)
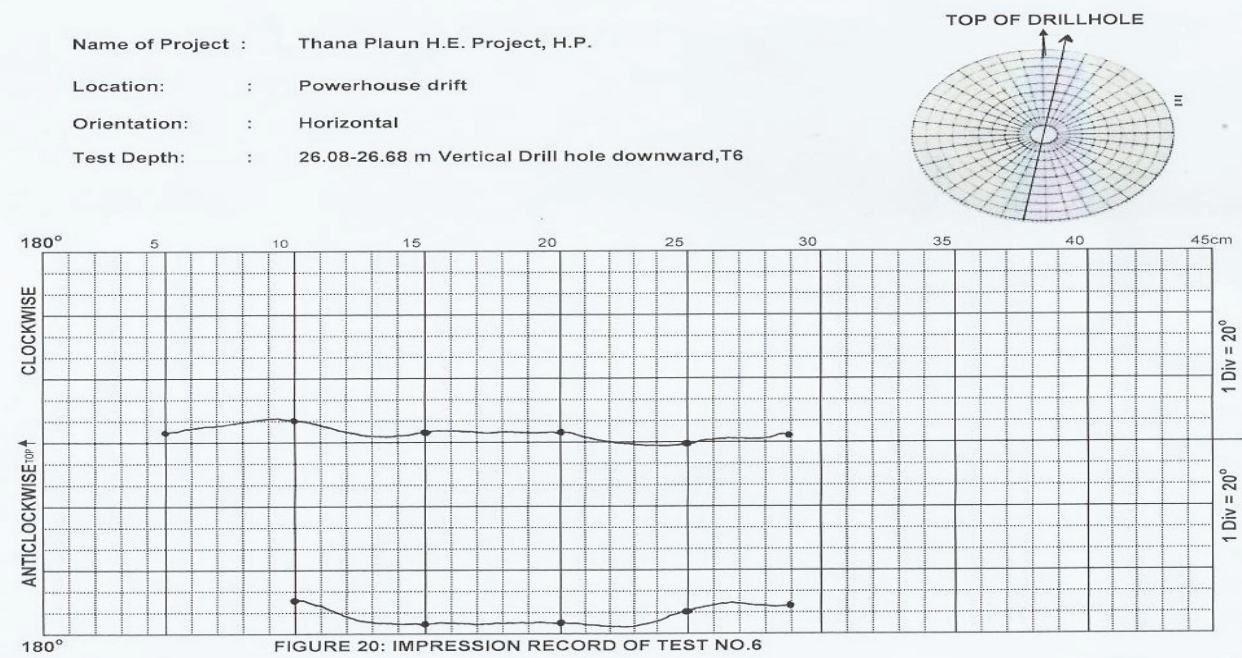

Fig. 4: Fracture impression record of Test No. 6 (DHF-1) (CSMRS, 2014) 
TABLE III: IN-SITU STRESSES FROM HORIZONTAL DRILL HOLES IN THE POWER HOUSE DRIFT (CSMRS, 2014)

\begin{tabular}{|c|c|c|c|c|c|c|c|c|c|}
\hline \multirow{2}{*}{ 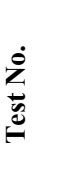 } & \multicolumn{2}{|c|}{ Test Depth } & \multirow{2}{*}{$\begin{array}{c}\mathbf{P i} \\
(\mathbf{M P a})\end{array}$} & \multirow{2}{*}{$\operatorname{Pr}(\mathbf{M P a})$} & \multirow{2}{*}{$\mathrm{Si}(\mathrm{MPa})$} & \multirow{2}{*}{$\begin{array}{c}\text { Sec. } \\
\text { Max. Stress } \\
\sigma_{1}^{\prime}(\mathrm{MPa})\end{array}$} & \multirow{2}{*}{$\begin{array}{c}\text { Sec. } \\
\text { Min. Stress } \\
\sigma_{2}^{\prime}(\mathrm{MPa})\end{array}$} & \multirow{2}{*}{$\begin{array}{l}\sigma_{\mathrm{v}}(\mathrm{MPa}), \\
\text { estimated }\end{array}$} & \multirow{2}{*}{$\begin{array}{l}\text { Orientation of } \\
\text { Maximum Stress } \\
\text { w.r.t Top of drill } \\
\text { hole }\end{array}$} \\
\hline & From & To & & & & & & & \\
\hline \multicolumn{10}{|c|}{ Location $=1$, RD $25 \mathrm{~m}$, DHF-1, Horizontal hole at Face (DHF-1) Bearing $265^{\circ}$ from north } \\
\hline T6 & 26.68 & 26.08 & 9.66 & 3.5 & 2.76 & 4.83 & 2.76 & \multirow{5}{*}{3.32} & $10^{0}$ \\
\hline $\mathrm{T7}$ & 24.5 & 23.90 & 11.73 & 4.8 & 3.11 & 4.49 & 3.11 & & \\
\hline T8 & 23.4 & 22.8 & 10.69 & 4.1 & 2.76 & 4.14 & 2.76 & & \\
\hline T9 & 14.3 & 13.7 & 11.04 & 4.5 & 2.93 & 4.31 & 2.93 & & $40^{0}$ \\
\hline T10 & 5.2 & 4.6 & 10.0 & 3.8 & 3.11 & 5.52 & 3.11 & & \\
\hline \multicolumn{10}{|c|}{ Location $=1$, RD $25 \mathrm{~m}$, DHF-3, Horizontal hole at Side wall (DHF-3) $355^{\circ}$ from north } \\
\hline T11 & 14.15 & 13.55 & 10.35 & 3.8 & 2.93 & 5.0 & 2.93 & \multirow{4}{*}{3.32} & $20^{0}$ \\
\hline T12 & 12.65 & 12.05 & 8.28 & 3.1 & 2.42 & 4.14 & 2.42 & & $25^{0}$ \\
\hline T13 & 11.15 & 10.55 & 11.39 & 4.8 & 3.11 & 4.49 & 3.11 & & - \\
\hline T14 & 8.15 & 7.55 & 12.42 & 5.2 & 3.8 & 6.21 & 3.45 & & $80^{\circ}$ \\
\hline \multicolumn{6}{|c|}{ Overall Average Value from both the locations of horizontal holes } & 4.81 & 2.94 & 3.32 & \\
\hline
\end{tabular}

\section{CONCLUSIONS}

Hydraulic fracturing is a borehole field-tests method designed to assess the state of in situ stress in rock-mass. These tests result is an estimate of the state of in situ stress (both magnitudes and directions) in the plane perpendicular to the axis of the borehole. These in-situ stresses are required in the design of tunnel lining thickness and type of lining as well as modelling of pre-existing stresses in rock media for the purpose of numerical modelling which would ultimately optimize the support system.On the basis of fourteen tests conducted at powerhouse site of Thana-Plaun hydroelectric project, the average values of maximum and minimum horizontal stresses were calculated in powerhouse drift. Vertical stress was estimated from the depth of over burden at the test locations and the same was interpreted from the tests in horizontal hole also. The maximum and minimum horizontal stresses in power house drift were determined as 5.49 $\mathrm{MPa}$ and $3.07 \mathrm{MPa}$, respectively. The average estimated vertical stress from the overburden/ rock cover is $3.32 \mathrm{MPa}$ whereas the measured stress from tests in horizontal drillholes was of the order of $3.45 \mathrm{MPa}$. Ratios of maximum horizontal stress to measured vertical stress and minimum horizontal stress to measured vertical stress were found as 1.59 and 0.89 , respectively. The average orientation of maximum horizontal stress obtained from the impressions of the fractures in vertical drillholes was found to be $N 78^{\circ} \mathrm{E}$.

\section{REFERENCES}

[1] Brown, E.T. and Hoek, E. (1978), "Trends in relationships between measured rock in situ stresses and depth", Int. J. Rock Mech. Min. Sci. \& Geomech. Abstr. 15, pp.211-215.

[2] Brown, E.T. 1987. Introduction. Analytical and computational methods in engineering rock mechanics, (ed. E.T. Brown), 1-31. London: Allen and Unwin.

[3] Ljunggrena C, Y Chang, T. Janson. and R. Christiansson. (2003),"An overview of rock stress measurement methods" Int. J. Rock Mech. Min. Sci. 40, pp.975-989

[4] Courtillot V. and G.E. Vink (1983), "How continents break-up", Sci. Am., 249, 42-49.

[5] CSIRO (1991), CSIRO Minifrac System Operational Manual, Mindata Pvt. Ltd., Australia, March 1991.

[6] Dewey, J.F. (1972), "Plate tectonics", Scientific American, 226, 5668.

[7] Engelder T. and Sbar, M.L. 1984. Near-surface in situ stress: introduction. J. Geophys. Res. 89, pp.9321-9322. Princeton, NJ: Princeton University Press.

[8] Hast N. (1958), "The measurement of rock pressure in mines", Sver. Geol. Under. Ser. C. 52: 1-152.

[9] Herget, G. (1988), "Stresses in rock", Rotterdam: Balkema.

[10] ISRM (1981): International Society for Rock Mechanics (ISRM) suggested methods for rock characterization, testing and monitoring, Editor: E.T. Brown, Published by Pergamon press, pp. 1-211.

[11] Report on stress measurements by hydro fracturing test in power house drift of thana plaun hydro electric project, himanchal pradesh CSMRS/12/2014.

[12] Mckenzie,D.P and J.G. Sclater (1973), The evolution of the Indian ocean. Scientific Amirican 288(5):62-70.

[13] Terzaghi, K. and Richart, F.E. 1952. Stresses in rock about cavities. Geotechnique 3, 57-90. 